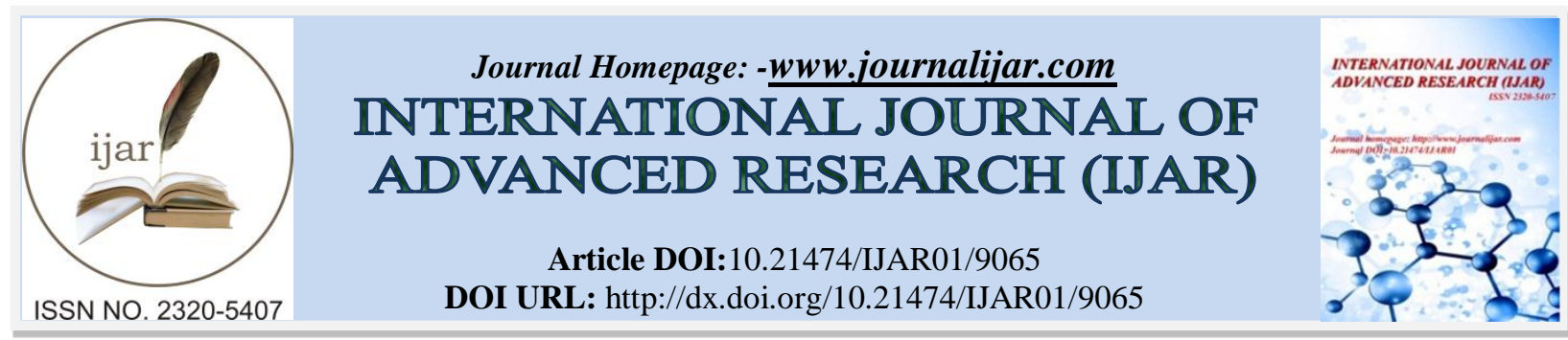

RESEARCH ARTICLE

\title{
CHANGES IN TOTAL LIPID CONTENT IN THE LIVER OF THE FRESHWATER FISH, MYSTUS SEENGHALA (SKYES 1839), EXPOSED TO SUBLETHAL CONCENTRATION OF METHOMYL $40 \%$ SP CARBAMATE INSECTICIDE.
}

Kashid Tanaji ${ }^{1}$, Jawale Chandrakant ${ }^{2}$ And Sonawane Doulat ${ }^{3}$.

1. Department of Zoology, PDEAs Anantrao Pawar College, Pirangut 412115, Pune Maharashtra, India.

2. Department of Zoology. Shri Madhavrao Patil Mahavidyalaya, Murum 413605, Osmanabad, Maharashtra, India.

3. Department of Zoology, Dr. Babasaheb Ambedkar Marathwada University, Aurangabad, Maharashtra, India.

\section{Manuscript Info}

Manuscript History

Received: 14 March 2019

Final Accepted: 16 April 2019

Published: May 2019

Key words:-

Sublethal concentration, Methomyl, Liver, Lipid, Toxicant.

\section{Abstract}

This study has been undertaken to investigate the impact of sub lethal concentration of Methomyl $40 \%$ SP Carbamate insecticide on total Lipid content in the liver of freshwater fish Mystus seenghala (Skyes 1839). During our present investigation fishes were exposed to the sublethal concentration (1/10th of $96 \mathrm{hr} \mathrm{LC}_{50}$ concentration) of Methomyl $40 \%$ SP a carbamate insecticide for 10, 20 and 30 days respectively. The total Lipid content in the liver tissue was determined by the standard procedure from control fish and the fish exposed to sublethal concentration of Methomyl $40 \%$ SP a carbamate insecticide. The results showed a significant decrease in the total Lipid content in liver tissues exposed to Methomyl a carbamate insecticide. The reduction in total Lipid content indicates that the test fish response to the toxicant stress.

Copy Right, IJAR, 2019,. All rights reserved.

\section{Introduction:-}

The use of insecticides has been recently increased as compared to organochlorine pesticides due to their high selectivity and lower persistence in the environment. Insecticides enter surface water via air drift, leaching from agricultural land and surface runoff during or after the application of pesticides (Goulding et al., 2013).

Fishes are in direct contact with the surrounding water through their gills. Pesticides have an effect on non-target animals like fish. Pesticides are extremely harmful, not only to fishes but also to different organisms. The intake of pesticides affects the biochemical composition of fishes (Shoaib N. et al. 2013).

Mystus seenghala (Skyes 1839) is found in large rivers, reservoirs, canals, flooded fields and ponds. The vernacular name of Mystus seenghala is "Shingta" in Maharashtra; Mystus is a predatory fish, feeds on other fishes. It is one of the largest edible fish. It is considered to be a very important food fish. Mystus seenghala fish species belong to the Cyprinidae family that is found in most rivers in India (Verma P. S. 2010). The wide distribution of the freshwater fish Mystus seenghala makes this species a potential and useful biomarker for monitoring aquatic ecosystems. Therefore, the aim of the present study was to investigate the changes in total Lipid content in the liver of the

Corresponding Author:-Kashid Tanaji.

Address:-Department of Zoology, PDEAs Anantrao Pawar College, Pirangut 412115, Pune

Maharashtra. India. 
freshwater fish Mystus seenghala (Skyes 1839) after exposure to sublethal concentration of carbamate insecticide (Methomyl 40\% SP).

\section{Material and methods:- Experimental Test Fish}

For the present study, the live freshwater fish Mystus seenghala (Skyes 1839) $(13 \pm 2 \mathrm{~cm})$ were collected in polythene bags from river Bhīma of Pune district (M.S.) India, and brought to the laboratory. Care was taken to reduce hyperactivity and physical injuries to the fish. They were screened for any possible pathological symptoms. They were then kept in large Aquarium tank of 20 litre capacity and then acclimated in chlorine free water for 10 days under normal temperature. Before stocking, the tank was washed with $1 \% \mathrm{KMnO} 4$ to avoid the fungal infection. Water was changed in alternate days. The fishes were fed a commercial fish diet.

\section{Experimental design}

Well acclimatized freshwater test fish Mystus seenghala (Skyes 1839) approximately length (13 $\pm 2 \mathrm{~cm}$ ) and average weight ( $17 \pm 2 \mathrm{gm}$ ) were selected from the stock and exposed to sub lethal concentration of Methomyl $40 \%$ SP for 10, 20, 30 days respectively to investigate impact of sub lethal concentration of Methomyl on total Lipid content in the liver. In the present study $1 / 10$ th of $96 \mathrm{hr} \mathrm{LC}_{50}$ concentration of Methomyl $40 \%$ SP carbamate insecticide was selected as sub lethal concentration. The experiments were carried out in glass aquarium with 10 fishes each. The experimental medium was renewed daily till the end of the experiment. The experiment was repeated five times and the mean values recorded separately for test fish. Simultaneously 10 fishes were reared in pesticide-free medium and are treated as control for the experiment.

\section{Estimation of Lipid content}

Estimation of total lipid was carried out by Barnes and Blackstock (1973) method.

$100 \mathrm{mg}$ wet tissue was homogenized in $20 \mathrm{ml}$ chloroform - methanol mixture using a glass homogenizer, filtered through Whatman No.1 filter paper and to this was added $4 \mathrm{ml}$ of $0.9 \% \mathrm{NaCl}$ solution. This mixture was shaken well and transferred to a separating funnel and was allowed to stand overnight at $4{ }^{\circ} \mathrm{C}$. A clear biphasic layer was formed with the lower phase containing all the lipids. The upper phase was discarded and lower phase was collected and the volume was made up to $10 \mathrm{ml}$ by the addition of chloroform. This was transferred to a $50 \mathrm{ml}$ beaker and the solvent was allowed to evaporate at $50-60^{\circ} \mathrm{C}$ for five hours. Then $5 \mathrm{ml}$ of concentrated $\mathrm{H}_{2} \mathrm{SO}_{4} \mathrm{was}_{\text {added to it, }}$ mixed well, and placed in boiling water bath for 10 minutes, then cooled to room temperature. $0.2 \mathrm{ml}$ of this sample was taken in a test tube and $5 \mathrm{ml}$ of phosphovanillin reagent was added. Mixed well, and was allowed to stand for 30 min. Standard was prepared by mixing $0.2 \mathrm{ml}$ of standard cholesterol and $5 \mathrm{ml}$ of phosphovanillin reagent, allowing it to stand for half an hour. Blank was prepared by taking $0.2 \mathrm{ml}$ of chloroform and $5 \mathrm{ml}$ of phosphovanillin reagent. Absorbance of test and standard samples against the blank were measured at $520 \mathrm{~nm}$ by calorimeter. The total Lipid content expressed as in $\mathrm{mg} / 100 \mathrm{mg}$ wet weight of tissue.

\section{Results and Discussion:-}

The total lipid content in the liver of the test fish Mystus seenghala treated with the sub lethal concentration of Methomyl $40 \%$ SP for different exposure period interval showed that reduced trend. The changes in the level of total Lipid contents in the liver of the fish, Mystus seenghala, were given in the Table No. 1 and Figure No. 1.

Table No 1:-Effect of Sub lethal concentration of Methomyl (0.42 ppm) (1/10th of 96hr $\mathrm{LC}_{50}$ value i.e. $\left.4.2 \mathrm{ppm}\right)$ on total Lipid content (mg/100mg) in the liver tissues of Mystus seenghala after chronic exposure.

\begin{tabular}{|l|l|l|l|l|}
\hline Organ & Control & Exposure Period & 30 Days \\
& & $\begin{array}{l}\text { 10 Days } \\
(\mathbf{0 . 4 2} \mathbf{~ p p m})\end{array}$ & $\begin{array}{l}\text { 20 Days } \\
(\mathbf{0 . 4 2} \mathbf{~ p p m})\end{array}$ & $\mathbf{( 0 . 4 2}$ ppm) \\
\hline Liver & & $05.45 \pm 0.32$ & $04.96 \pm 0.21$ & $03.46 \pm 0.12$ \\
& $06.19 \pm 0.12$ & $(11.95)$ & $(19.87)$ & $(44.10)$ \\
\hline
\end{tabular}

1. Each values are expressed in $\mathrm{mg} / 100 \mathrm{mg}$ wet wt. of tissue.

2. Each value indicates the mean $(X \pm S D)$ of five estimations.

3. Figures in bracket indicate difference in percentage over control. 


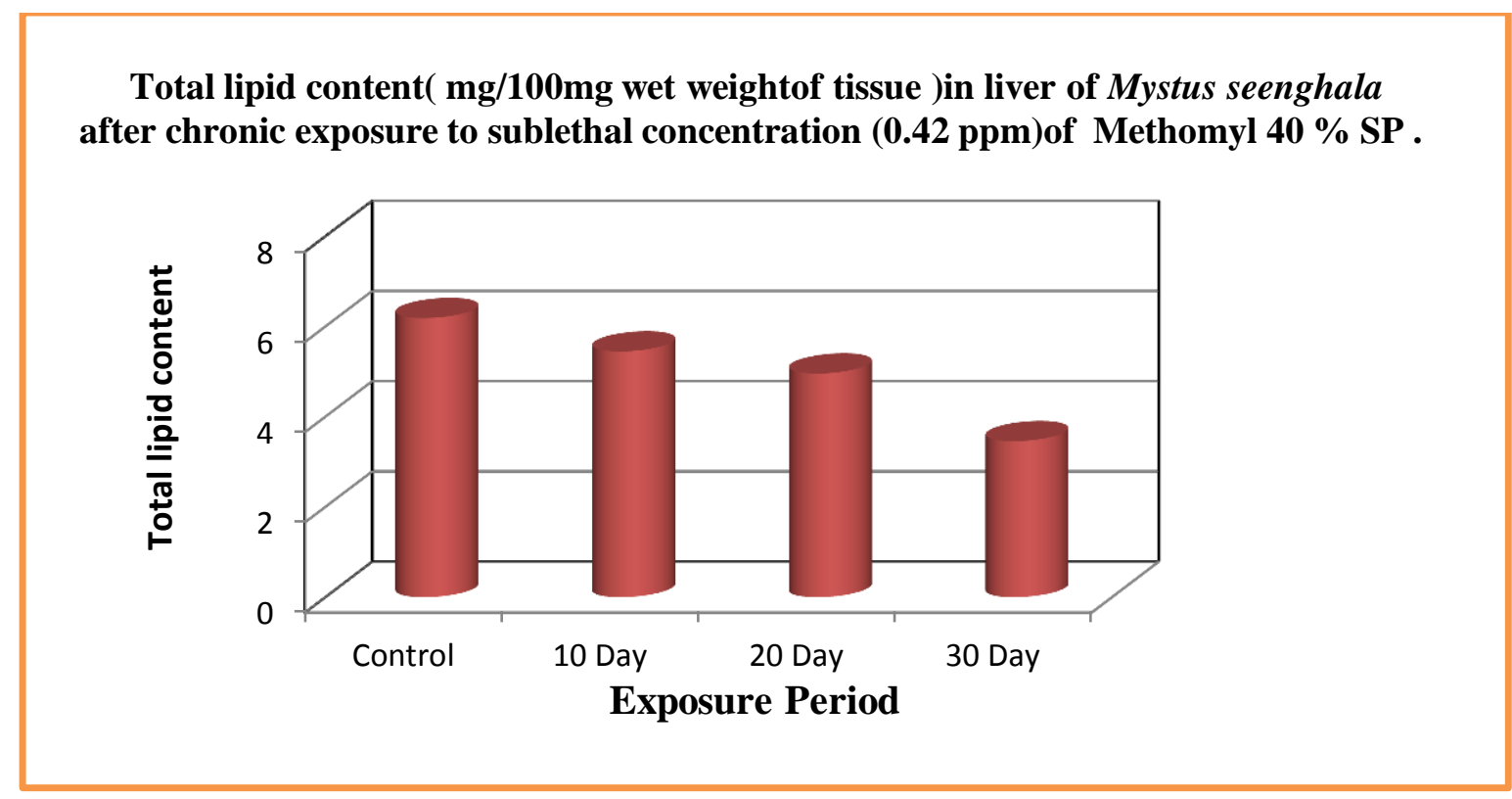

Figure No 1:-Effect of Sub lethal concentration of Methomyl 40\% SP (0.42 ppm) on total Lipid content (mg/100mg) in liver tissues of Mystus seenghala after chronic exposure

Total Lipid content in liver showed a decline trend to $05.45 \pm 0.32 \mathrm{mg} / 100 \mathrm{mg}$ wet tissue on 10th day. It was found to have been further reduced to $03.46 \pm 0.12 \mathrm{mg} / 100 \mathrm{mg}$ wet tissue after 30 days of exposure period at the $0.42 \mathrm{ppm}$ sub lethal concentration of Methomyl $40 \%$ SP, which was equivalent to $44.10 \%$ reduced from the control value $(06.19 \pm 0.12 \mathrm{mg} / 100 \mathrm{mg}$ wet tissue $)$.

In the test fish, total Lipid contents in the liver recorded were $05.45 \pm 0.32,04.96 \pm 0.21$ and $03.46 \pm 0.12$ $\mathrm{mg} / 100 \mathrm{mg}$ wet tissue at $0.42 \mathrm{ppm}$ sublethal concentration of Methomyl $40 \% \mathrm{SP}$ for 10, 20 and 30 days of exposure respectively. The percentage of reduction in liver total Lipid content over the control was $11.95 \%, 19.87 \%$ and $44.10 \%$ after 10, 20 and 30 days of exposure respectively.

In the present study there is decline in total Lipid content in the liver tissue was recorded in the freshwater fish Mystus seenghala exposed to toxicant methomyl 40\% SP.. Decrease in total lipid in tissues might be due to drastic decrease in glycogen content in the same tissue which is an intermediate source of energy during toxic stress conditions. After glycogen, lipid content may be used for energy production to overcome toxic stress. Some workers support these results in which lipid content decreased in fishes after exposure to pollutants. Tripathi and Verma (2004) reported changes in protein, glycogen and lipid content in the liver and muscle tissues of the freshwater fish, Clarias batrachus L treated with endosulfan. Singh and Singh (2006) reported changes in tissue lipids, phospholipids and protein profile in the male Heteropneustes fossilis Bloch exposed to sub lethal concentrations of endosulfan. Amudha et al. (2002) investigated that the effect of dairy effluent on $O$. mossambicus and reported that lipid content was decreased. Similarly decreases in lipid content level were observed by Swapna et. al., (2006) in Cyprinus corpio exposed to textile effluent. Shruti S. Gijare et. al., (2011) also reported that decrease in total lipid content in the liver in freshwater fish Ophiocephalus punctatus exposed to synthetic pyrethroid cypermethrin. Israel stalin S. and Sam Manohar Das. S. (2012) reported that maximum decline in total lipid content in the liver tissue of fish Cirrhina mrigala (Hamilton) exposed to Fenthion after 30 days.

\section{Conclusion:-}

In the present study, the significant depletion in Lipid content was observed in liver tissue of test fish Mystus seenghala after chronic exposure to sub lethal concentration of methomyl40 \% SP a carbamate insecticide. A decrease in the total lipid content of the liver exposed to carbamate insecticide suggests that lipid might have been utilized for energy production for other metabolic functions during toxic stress conditions. 


\section{Acknowledgment:-}

Author is thankful to Principal PDEA's Anantrao Pawar College, Pirangut and Head, Department of Zoology, Dr. Babasaheb Ambedkar Marathwada University, Aurangabad for providing laboratory facilities during the present work.

\section{References:-}

1. Amudha P. Sangetha G. and Mahalingam S. (2002). Diary induced alterations in the protein, carbohydrate and lipid metabolism of fresh water teleost fish Oreochromis mossambicus. Poll. Res. 21: 51-53.

2. Barnes, H. and Blackstock, J. (1973). Estimation of lipids in marine animals and tissues: Detailed investigation of the sulphophosphovanillin method for 'total' lipids. J. Exp. Mar. Biol. Ecol., 12: 103 - 118.

3. Goulding A.T., Shelley L.K., Ross P.S., Kennedy C.J. (2013). Reduction in swimming performance in juvenile rainbow trout (Oncorhynchus mykiss) following sublethal exposure to pyrethroid insecticides. Comparative Biochemistry and Physiology, Part C, 157: 280-286.

4. Israel Stalin.S, Sam Manohar Das.S (2012). Biochemical changes in certain tissues of Cirrhina mrigala (Hamilton) (Cyprinidae: Cyprniformes) exposed to fenthion, International Journal of Environmental Sciences 2(3): 1268-1277. doi:10.6088/ijes.00202030013

5. Shoaib, N., Siddiqui, P.J.A. and Khalid, H. (2013). Toxicity of synthetic pyrethroid pesticides, fenpropathrin and fenvalerate, on killifish Aphanius dispar juveniles. Pak. J. Zoo.45 (4) :1160-1164.

6. Shruti S. Gijare, I. A. Raja, V. T. Tantarpale and K. M. Kulkarni (2011). Lipid changes in freshwater fish Ophiocephalous puntatus exposed to synthetic Pyrethroid Cypermethrin. Biosci. Biotech. Res. Comm. 4(1): June 2011, 52-54.

7. Singh, PB. And Singh, V (2006). Impact of endosulfan on the profiles of phospholipids at sublethal concentration in the male Heteropneustes fossilis Bloch. Journal of Environmental Biology, 27(3): 509-514.

8. Swapna S. B. Dhankkodi and M. Manimengalai (2006). Effect of textile bleaching effluent on the food utilization, oxygen consumption and biochemical composition of Cyprinus carpio. Poll. Res.25 (4): 741-745.

9. Tripathi, G. and Verma, P. (2004). Endosulfan mediated bio-chemical changes in the fresh water fish Clarias batrachus. Biomedical and Environmental Science, 17: 47-56.

10. Verma P.S. (2010). Revised edition a manual of practical zoology Chordates, S. Chand publication, pp. 155. 